\title{
The Impact of Using Picture Books with Preschool Students in Taiwan on the Teaching of Environmental Concepts
}

\author{
Ching-Yuan Hsiao ${ }^{1} \&$ Pei-Yu Shih ${ }^{2}$ \\ ${ }^{1}$ Department of Early Childhood Education, National University of Tainan, Tainan, Taiwan \\ ${ }^{2}$ Kaohsiung Municipal Chung-Te Elementary School, Kaohsiung, Taiwan \\ Correspondence: Ching-Yuan Hsiao, Department of Early Childhood Education, National University of Tainan, \\ 33, Sec. 2, Shu-Lin St., Tainan 700, Taiwan. Tel: 886-929-040-353. E-mail: cyh111@mail.nutn.edu.tw
}

\author{
Received: September 1, 2014 Accepted: November 19, 2014 Online Published: February 25, 2015 \\ doi:10.5539/ies.v8n3p14 URL: http://dx.doi.org/10.5539/ies.v8n3p14
}

\begin{abstract}
The aim of this study was to investigate preschool teachers' use of picture books for teaching environmental concepts and the conservation of resources. Using an action research approach, twelve children aged 5-6 years old were recruited for this eight-week study. Eight picture books with an environmental education theme were selected for use in these classes. The results revealed that the pupils' knowledge of environmental concepts was higher in the post-test than the pre-test. With regard to the conservation of resources, the children learned to bring their own cotton hankies, use less water when washing their hands and brushing their teeth, and reduce the amount of drawing papers on which they doodled. The children were also persuaded to continue saving energy at home, and demonstrated that they understood that turning off the TV and lights were practical steps they could take to achieve this. Nevertheless, they did not appear to grasp the idea of reusing plastic bags.
\end{abstract}

Keywords: environmental education, environmental concepts, picture books, preschooler, resources conservation

\section{Introduction}

During the course of a recent study the researcher found that preschoolers often did not know what it meant to cherish water resources and also wasted art materials, painting a few strokes on a piece of paper and then throwing it away. Attempts to verbally persuade them to be more environmentally conscious did not work, leading the researcher to consider methods of educating preschool children about the concepts of environmental protection and resource conservation through instruction using a series of picture books. The goal was to increase preschool children's positive ideas and attitudes toward the environment.

\subsection{Purpose and Objectives}

This study was based on the action research method; picture books were used in the development of activities centered around educating children on the environment. The curriculum involved the use of a series of picture books in activities focusing on environmental education. The purpose of this study was to investigate whether instruction with picture books influenced children's understanding of the importance of saving natural resources.

\section{Literature Review}

\subsection{The Importance of Environmental Education}

Social development and technological advances have led the earth into a serious ecological imbalance. Men \& women are finally becoming aware of environmental problems and making environmental education an important part of global education. Allman, Kopp, and Zufelt (1982) were the first to advocate for environmental education and divided this topic into 11 categories that included forest conservation, land conservation, air pollution, natural balance, animal conservation, water resources, community issues, and so on. After Agenda 21 was proposed at the 1992 Earth Summit, environmental education became not only necessary for world citizens but also the responsibility of all countries on the Earth (Ministry of Education, 2003). The Ministry of Education (MOE) included environmental education as one of six major issues in the Grade 1-9 Curriculum in Taiwan. The education bureau's goal is to develop students' awareness of and sensitivity to the environment through the power of education. The goals of environmental education are to: use education to develop students' 
understanding of their ethical relationship with environment, enhance the skills and concepts of environmental education, encourage students to pay greater attention to the environment and take actions to achieve sustainable development of the civic education process. Thus, environmental education has become a popular and thoughtful issue.

Witt and Kimple (2008) noted that the childhood period is the strongest for absorbing new concepts; thus, the preschool period is the best time for environmental education. Moreover, many scholars already offer environmental education in elementary schools - these courses have received very good feedback. Participation in environmental education could enhance the saving of natural resources. Application of different instructional strategies may increase children's environmental awareness (Aguirre-Bielschowsky, Freeman, \& Vass, 2012; Ahlness, 1999; Chang, 2004; Hadzigeorgiou et al., 2011; Heish, 2012; Kao, 2011; Sun, 2011; Tarr, 2008; Witt \& Kimple, 2008). According to the studies cited above, any of several activity designs may be used in environmental education to lift children's awareness of and sensitivity to environmental issues, as well as their care for the environment and engagement in practical actions. In addition, Tien and $\mathrm{Wu}(2010)$ also believed that children aged 5-8 years were the best target population for picture book instruction related to environmental education. However, R. Monhardt and L. Monhardt (2000) also noted that children only become environmentally aware and engage in environmentally conscious behavior temporarily during their early years.

\subsection{The Impact of Picture Books on Children}

More and more researchers are using picture books as the media for instruction in different subjects due to their following functions. Hirsh-Pasek and Golinkoff (2003) indicated that picture books may be a natural and non-threatening way to help children develop skills and learn important concepts. Tanner (1980) stated that since environmentalists had experienced nature in childhood, the environment has greatly influenced their attitudes and was the driving force behind their commitment to protect the environment. Debby (2007) stated picture books are easily accessible, and can stimulate cognitive and cultivate emotional value. Many children experts also have pointed to the educational value and function of picture books, such as enhancing cognitive learning, fostering creativity imagination, promoting language learning, providing emotional identity, cultivating kindness and caring heart, appreciating aesthetics, promoting literacy activities and reading habits (Chien, 2004; Feng, 2003; Hsiao, 2010; Hsiung, 1996; Hsu, 2010; Lin, 2000; Liu, 2002; Walden \& Baxter, 1989). Nevertheless, Chawla (1998) believed that children have a compassionate personality, so that the early childhood period was one of the most suitable periods for the implementation of environmental education.

Taiwan researchers have used picture books in environmental education with elementary school children with good results, enhancing their concept of environmental and learning skills (Chen, 2009; Kuo, 2008; Liu et al., 2010; Liu \& Wang, 2003; Ning, 2005; Wang, 2011; Wang \& Hu, 2002). Wells and Zeece (2007) referred to recent studies which showed that people of all ages lacked environmental science knowledge. One remedy is the use of picture books to foster science development in children while simultaneously helping them to understand their living environment. Nevertheless, these studies mostly focused on elementary school students and emphasized environmental awareness; past research has seldom involved preschoolers as research subjects and in explorations of practical actions. Liu et al. (2010) found that simply reading a picture book could improve children's environmental knowledge, especially as it impacts their everyday lives. To foster environmentally friendly attitudes and behaviors, it was necessary to practice the self-designed Little Green Sprout lesson plans for processing environmental instruction in preschool. All in all, the goal of this study was to use picture books to help them contribute to safeguarding the planet, to increase children's awareness of environmental issues, develop good natural resource-saving habits.

\section{Research Methodology}

\subsection{Participants}

Study participants were twelve children aged 5-6 years from a rural public preschool-5 boys and 7 girls. The homeroom teacher who assisted this research was Ms. Jade, who received a master's degree from the teacher's college and performs collaborative work. Her role in the research was a co-teacher and recorder, and she also acted as an observer for the content validity of the data analysis. The researcher often exchanged opinions with her while revising the curriculum and instruction on environmental education. In addition, the data and findings were checked by the environmental professor for investigator triangulation.

\subsection{Research Tools}

\subsubsection{Pre- and Post-Test Questionnaires on Environmental Concepts}

The researcher selected eight picture books related to environmental education, and designed pre- and post-test 
questionnaires on environmental issues as these were portrayed in the picture books. Each questionnaire had ten questions, and the results from both were analyzed to assess the children's understanding of environmental concepts before and after picture book instruction.

\subsubsection{Questionnaires for Parents}

To better understand the children's habits with regard to resource use at home, and identify the environmental practices in which they engaged; the researcher developed a questionnaire for parents that enabled a comparison of behavior before and after implementing the course of environmental education.

\subsubsection{Picture Books on Environmental Education}

The EPA (Environmental Protection Administration) in 2004, 2006 and 2007 held a Little Green Sprout Awards competition, to select those picture books deemed excellent in conveying the environmental education message in Taiwan. The award-winning picture books communicated about both humans and the environment, and the respect for life and care about the earth's importance, to encourage children to make environmentally friendly choices in their daily life. These books were very suitable as environmental education reading for preschoolers. The researcher reviewed these award-winning picture books and selected four that were more suitable for children and relevant to the research topics. These books were: Carnival of the Animals, Forest Fear, The Changing Countryside, and The Thrifty Grandma. Four others were also selected-I Stink, Look after Your Planet, Super Bee's Environmental Life, and The Journey of Running Water-that had not received Little Green Sprout Awards but were interesting and fit the concepts and approaches of this research. After discussing these picture books with environmental experts, it was decided to use them as research tools.

\subsubsection{Environmental Concepts Checklists}

This research also used environmental concepts checklists, which the researcher self-designed according to instructional objectives. These checklists were akin to oral quizzes that were given to the children after each instructional activity to evaluate its effectiveness. Furthermore, the environmental concepts checklists were implemented by the researcher and then discussed with the homeroom teacher to determine whether the children's responses had included environmental references as delivered by the researcher.

\subsubsection{Homeroom Teacher's Interviews}

The homeroom teacher would spontaneously convey to the researcher any occasions on which she observed children's study-related behaviors. The researcher also conducted a number of interviews with the homeroom teacher after picture-book instructional activities.

\subsubsection{Design of Instructional Activities and Implementation}

The researcher set teaching objectives, and designed the curriculum and instruction activities according to the eight picture books. The researcher conducted the picture books instruction activity for one hour on a Wednesday and expanded those activities the next day during the Interest Center period. This was an eight-week program in which data were collected on the instructional process via digital video recording. The principle of instructional activities design was combined with practice methods for instruction using picture books by Feng (2003) and Ning (2004). The sessions included warm-up activities before instruction, picture book appreciation and discussion, and expanded activities after picture book instruction. The expanded activities were mainly conducted in multiple ways, including drawing, film appreciation, game playing, music, song and movement, dramatic plays, and so on.

\subsection{Data Analysis}

Data analysis for this research included observation records, reflection journals, feedback from the homeroom teacher, pre- and post-test questionnaires, and children's environmental concept checklists. To easily analyze and record the data, the researcher classified data according to categories and dates and then conducted the inductive reasoning/triangulation method.

\section{Findings and Discussion}

The aim of this research was to investigate the influence of instruction with picture books on children's learning of environmental concepts, focusing mainly on resource conservation. In exploring the before- and after-effects of picture book appreciate activities on children's learning of environmental concepts, the researcher compared the pre-test and post-test of the environmental concept questionnaires. The researcher analyzed the data according to the following methods: parents' pre- and post-test questionnaires, to understand whether picture book instruction actually influences children's learning of environmental concepts and their practical engagement in resource conservation, and through examining observation records with the homeroom teacher. 
Furthermore, the homeroom teacher's opinions were collected by the researcher during research procedures, or the homeroom teacher would spontaneously inform the researcher if there were any discoveries during the research process.

\subsection{Impact on Children's Learning of Environmental Concepts through Picture Book Instruction}

The researcher used the one-on-one method from the design of picture books and environmental concept questionnaires to process the pre- and post-test.

\subsubsection{Analysis of Children's Reaction to Carnival of the Animals-Certain Approaches Affect Animals' Behaviors}

In the pre-test questionnaire, children's responses were very common, such as kill animals, trampled animal to death, eat animals, etc. However, children could more specifically express approaches to how human beings hurt animals, such as cut important parts of animals or peel skin of animals, in the post-test questionnaire. The children's responses on the post-test questionnaire indicated their understanding of the level of harm to animals, from small animals to large wild animals. Children also could express desires not to cut many trees, not to kill animals for no reason, and not to feed food waste to animals or throw plastic bags in the ocean. Children thought everyone could protect animals in this way. Kuo (2008) also mentioned that students did upgrade their understanding of the living environment of wild animals by intervening in storytelling instruction; children also understood the concept of stopping the illegal hunting of wild animals. The students had the correct attitude about respect for life after her instruction. Furthermore, Hadzigeorgiou et al. (2011) also found the effectiveness of the storytelling approach in their environmental study.

\subsubsection{Analysis of Children's Reaction to Forest Fear and Carnival of the Animals-How Trees Can Help Human} Beings or the Environment

Children's responses on the pre-test indicated their recognition of trees' benefits to us, including: to enjoy the cool, to enjoy the fruits, to provide us with nutrition, and to make our body healthy; however, children had no idea about the benefit to entire environment. After picture book instruction, children responded that trees were able to prevent landslides, which was also one of the important environmental concepts that the researcher expected the children to acquire. In the post-test, children knew that trees could produce oxygen to make our bodies healthy - the percentage for this part improved by $32 \%$ compared to the pre-test. The researcher introduced the functions of trees in the expansion activities, and children knew that trees can be turned into various daily supplies, such as drawing papers and tissue papers. Thus, children's learning of environmental concepts improved by $32 \%$ compared to the pre-test. The concept of trees as the animals' home was hidden in Carnival of the Animals and Forest Fear; 36\% mentioned it after the instructional activity. In addition, 36\% learned that trees could make the environment more beautiful, which the researcher had introduced in the expansion activities. Hadzigeorgiou et al. (2011) study also presented that children knew trees' importance to human beings in the post-test. Liu and Wang (2003) also found that after a series of instructional activities related to environmental protection, children could understand the importance of environmental protection and became determined to protect the Earth.

\subsubsection{Analysis of Children's Reaction to Forest Fear-Cutting a Lot of Trees Has an Impact on Our Environment}

Before picture book instruction, $66 \%$ did not know that cutting a lot of trees would have an impact on our environment; only a few children could describe that the planet would be sick, the air would become black, animals would be unable to live on the trees. Thus, the researcher believed most of children's learning of environmental concepts was insufficient. After picture book instruction, children could more specifically describe bad influences, such as cutting lots of trees leads to landslides and animals would have no place to live, or it would become very hot if nothing provided shade from the sun. Those responses how that children already understand the function of trees and their importance to the Earth; children could also tell that they had to bring cotton hankies in their daily life to avoid overuse of tissue papers, use both sides of paper to prevent waste, and do paper recycling to reduce logging. Lin (2007) asked students to describe the relationship between plants and human beings in the instructional activity survey. After engaging in the instructional activity, students' responses could focus on the function of plants and their benefits to us, such as produce oxygen, provide food to human and beautify the environment. Thus, picture books could enhance cognitive learning, and help students construct a more concrete notion of environmental concept.

4.1.4 Analysis of Children's Reaction to the Changing Countryside-The Difference between the Past and Present Environment

Before picture book instruction, children were unclear about the difference between the past and present environment, only a few knew that in the past houses were low and flat-roofed, and that there were more trees, 
fewer cars, and fewer apartments, and that the sheep and cattle in the fields or some small wild animals could be readily seen. After picture book instruction, children mentioned that the present environment has many tall apartment houses and cars, and plenty of factories; animals are seldom seen; there are more people and lots of apartment houses; roads have been paved with asphalt, and there are supermarkets. All of this was learned from scenes in the picture book, The Changing Countryside. Children could realize the change of environment from a comparison among illustrations, which showed the difference between past and present environments. Ning (2005) also used the picture book, The Changing Countryside, to explore changes in the environment in his research. His results also revealed that after picture book instruction, students could use specific concepts in describing the characteristics of past and present environments. Most students believed that the present environment was polluted because of smoke and fumes produced by cars and factories.

\subsubsection{Analysis of Children's Reaction to Look after Your Planet and I Stink-Garbage Is Recyclable}

No matter what the responses in the pre- or post-tests, most of the children could describe the recyclable categories of glass, plastic, and paper. This was because these were the recyclable categories children normally learned about in school. In the post-test, children noted that appliances were also recyclable, as were clothes, tires, and batteries, fluorescent tubes and so on; those were not mentioned in the pre-test. Post-test results indicated that children knew more recyclable categories.

4.1.6 The Analysis of Children's Reaction to Look after Your Planet and I Stink-Habits in Daily Life could Reduce Garbage

In the pre-test, $25 \%$ did not know how to reduce the amount of garbage generated every day. Children's responses were mostly about not littering, picking up trash, or burying trash in the earth so that garbage would not be seen everywhere. These were considered good ways to reduce garbage in the pre-test. In the post-test, children said that they had learned practical approaches to lessening the amount of garbage, including using shopping bags, chopsticks and their own cups/mugs. Children also understood that the use of cotton hankies was another way to reduce waste. Overall, children learned that the best way to reduce garbage was through practical actions, and that hiding the garbage was not the best choice.

\subsubsection{The Analysis of Children's Reaction to the Journey of Running Water-Approaches to Water Conservation}

After the picture book instruction the children's recognition of various ways to save water improved - going beyond simply turning off a faucet when not being used. In the post-test the children answered that they knew how to take showers and baths that used less water, and that the water left after washing the rice could be kept for watering flowers or flushing the toilet. The children offered more details about these methods, such as not letting the water flow when washing dishes and vegetables, or brushing teeth. The children also knew that collecting rain water was another way to save water-although this was not mentioned on the pre-test questionnaire.

\subsubsection{The Analysis of Children's Reaction to the Thrifty Grandma-Approaches to Electricity Conservation}

A comparison of the pre- and post-test showed that children's concept of electricity conservation also improved. A total of $36 \%$ did not know how to save electricity; $40 \%$ knew that children must turn off electrical equipment when finished. The increase on these to $42 \%$ in the post-test was not significant. Parents' pre-test questionnaire revealed that ten children had already learned to spontaneously turn off the light/TV when they didn't need it anymore. Children already knew to turn off electrical equipment to save electricity. In the post-test, children could offer more ways to engage in electricity conservation, such as do not take the elevator instead of walking up the stairs, do not open the refrigerator frequently, and use energy-saving bulbs.

\subsubsection{The Analysis of Children's Reaction to the Thrifty Grandma-Approaches to Paper Conservation}

Children knew more about paper conservation in the post-test. In the pre-test, $36 \%$ did not know how to save paper, $16 \%$ used scrap paper to draw, and $16 \%$ children used the other side of paper to draw. Others mentioned not using too much paper, pointing to amount control. In the post-test, $50 \%$ indicated using both sides of papers when making artworks - an increase from the pre-test. The homeroom teacher and the researcher not only kept reminding children about paper conservation during the instructional process but educators also sought to be a good role models, taking the blank side of recyclable paper to re-use for print. The homeroom teacher and the researcher also tried their best to encourage children to turn overused paper and continue drawing at the art center, which had some influence on them. In addition, children already understood that reusing recycled paper also saved paper- $72 \%$ used recycled paper for drawing, and $72 \%$ used them to create artwork. 
4.1.10 The Analysis of Children's Reaction in the Pre- and Post-Test Questionnaires to Look after Your Planet-Environmentally Friendly Behavior

In the pre-test, $58 \%$ did not know about environmentally friendly behaviors. Other responses mainly related to garbage (no littering) and classified them as actions to take care of the Earth. Another 8\% were relevant to air pollution, having no idea about "environmentally friendly." In the post-test, the researcher knew that children had already acquired the environmental concepts conveyed in every picture book. Children understood that they should walk more or ride bicycles, bring green environmental tableware and shopping bags with them, do recycling, save electricity, save water, and practice these approaches, since all were environmentally friendly behaviors. Among the aforementioned eco-friendly approaches, the highest percentage focused on using cotton hankies $(80 \%)$. This may because the researcher and homeroom teacher always emphasized this and reminded them to do it.

\subsection{Children's Resource Conservation after Picture Book Instruction}

Resource conservation in this study referred to children's ability to save electricity, save water, and save resources such as paper, materials and toys in daily life. Study results indicated that the children already understood environmental concepts relating to resource-saving. Now the researcher analyzed the data from the children's practical actions, as recorded through observations, the homeroom teacher's opinion, children's responses, and parents' questionnaires.

4.2.1 The Number of Children Who Brought Cotton Hankies Increased, and the Consumption of Tissue Papers Decreased

The researcher and homeroom teacher kept reminding children to bring and use cotton hankies to reduce logging-an eco-friendly approach in this study. Moreover, useful methods were implemented, such as to establish the Love the Earth Declaration Tree and to deliver the Environmental Protection Guardians reward cards. The number of children who brought cotton hankies to school increased from 1-2 persons at the beginning of the study to 7-8 persons. The home room teacher noted that: "Currently many children aged 5-6 years did bring cotton hankies, so the consumption of tissue papers seems slower down a little bit. Besides, some children aged 4-5 years were also affected and would spontaneously bring cotton hankies to school."Her comment indicated that the actions of children aged 5-6 years would also affect children aged 4-5 years via demonstration and inspiration effects. According to the parents' questionnaires, seven parents declared that their children spontaneously brought cotton hankies to school compared to the beginning of the fall semester. Thus, children not only knew the importance of bringing cotton hankies but were willing to practice it. Hsieh, in her (2012) action research, asked children to learn about recycling through a series of environmental curriculum and instruction activities. She also found that many children become accustomed to bringing their own cotton hankies. The consumption of tissue paper significantly decreased after the action research. Moreover, she stated that children did understand that they can do something to protect the Earth by reducing the amount of their waste.

\subsubsection{Children Were Able to Save More Water When Washing Hands and Brushing Teeth}

The researcher found that children aged 5-6 years could spontaneously reduce water use when washing hands and did not need their teacher to remind them. Children would wash their hands quickly and turn off the faucet, used less water when brushing teeth. Children spontaneously showed their own cup to the homeroom teacher and declared that they did knowhow to adopt green products. When washing hands before snack time, a girl noticed a boy beside her who had used too much water and then spontaneously turned water off for him. Thus, children already knew the importance of water resources and could execute the required action. Children also replied that they could reduce water use when washing their hands, only used one cup of water when brushing teeth, took a shower instead of a bath, and followed many useful approaches to save water. When the researcher implemented the environmental concepts checklist, children made the following comments:

C1: I use very little water when brushing my teeth and would turn on a little water when washing my hands.

C5: I would use a shower and only one cup of water for brushing my teeth.

C8: I would turn off the tap if my mother did not turn it off properly.

4.2.3 The Consumption of Drawing Paper Was Reduced in Preschool, and Children Were More Willing to Use Recycled Paper or Scrap Paper When Making Artwork

Paper conservation was one of the main goals sought by the researcher. Before implementing the research, children often doodled on drawing papers and then discarded them - they did not know to use both sides of paper. 
And while children used scrap paper and advertising paper at the art center, they normally used them for doodling only, seldom when creating artworks. After implementing the research, the researcher found that the number of children who used scrap paper to draw increased, while the number who used new drawing paper decreased. Children also used scrap paper to make nice drawings. The homeroom teacher said that: "children were more willing to use recycle stuff to make creative artworks, some children aged 4-5 years could follow the example of children aged 5-6 years." She no longer had to remind the children not to waste drawing paper during the Interesting Center period. Children spontaneously used scrap paper to make nice drawings and also used both sides of drawing papers. In addition, the homeroom teacher seldom found papers with awful doodles. The researcher was satisfied with the result because children did practice the paper-saving approach. Ahlness (1999) presented a paper bag recycling project that had the same effect. According to parents' post-test, children were using recycled papers to draw or make creative artworks at home. Aguirre-Bielschowsky, Freeman, and Vass (2012, p. 91) also found students 'from schools with an EE program did translate environmental practices learnt at school into environmental practices at home.' Moreover, one parent said her child used scrap paper to make paper cut cuts.

4.2.4 Children Were Able to Spontaneously Turn off Lights and the Television, and Opened the Fridge Less Often to Save Electricity

Children had few opportunities to use electrical appliances at school, and did not use fans in the winter time, so the researcher was unable to observe whether children would be more active in turning off fans. Although the researcher could not know the extent of children's efforts to engage in electricity conservation at school, ten parents said that children were more likely to spontaneously turn off the lights and TV when children did not use them at home. Compared with the beginning of the fall semester, six parents said that children spent less time watching TV. Most children also indicated that they would spontaneously turn off lights and the TV at home, and would not often open the fridge. On the environmental concepts checklist, children made the following comments:

C3: I spontaneously turn off lights, the television, and do not keep opening the refrigerator door.

C7: I turn off the lights by myself, and do not often open the fridge.

C10: I turn off the television and ask my father to turn off the lights because I cannot reach the switch.

\subsubsection{Children's Reuse of Plastic Bags Was Not Improved}

Every morning four children aged 5-6 years always used new plastic bags to carry breakfast to school. Although children had already learned that going shopping with their own shopping bags was more eco-friendly, and that re-used plastic bags were suitable for meals brought to school, the four children still used new plastic bags. This might be because the homeroom teacher asked children to use recycled plastic bags for bone or food waste after lunch - the re-use of bags for trash might have carried certain connotations for the children when it came to conveying food to school. This may also have been due to family habits; parents' post-test questionnaires showed that three of the four children did not bring their own shopping bags when going shopping. Furthermore, since plastic bags were free, it was not easy to cultivate the habit of using recycled plastic bags.

\subsection{Brief Summary}

Sun (2011) indicated that the implementation of environmental education courses could help youngsters cultivate cognitive learning, psychomotor learning, and affective learning, and also promote problem-solving ability. These comments fit with this study. The researcher's main goals of teaching children to save water and paper, and bring cotton hankies rather than using tissue papers were achieved. Nevertheless, bringing their own/re-using plastic bags was not accomplished. Chen (2009) found that picture book instruction could cultivate students' ability to engage in environmental awareness and take action on water and electricity use, as well as reusing recycled paper and using their own cups. However, students did not pick up trash spontaneously in his study. Li (2007) also mentioned that the use of picture books in environmental education instruction could cultivate students' understanding of environmental education concepts; however, he also indicated that the implementation of environmental actions did not have immediate effects and lead to specific changes. In addition, Li (2007) also suggested that homeroom teachers had to be willing to offer constant and continuous guidance; the children also needed long-time cumulative learning and culture. At the beginning of the action research, the researcher and homeroom teacher constantly reminded children to implement green practices; children internalized those good habits. Moreover, the researcher believed that children would carry out those good habits throughout their lives. Chien (2004) also found that using picture books in instruction on environmental issues was most successful when related to children's living experience. This led children toward 
better learning and to apply lessons in their daily life.

\section{Conclusion} 5.1 Picture Book Teaching Helps Children to Save Resources Practically, but They Are Unable to Reuse Plastic
Bags Consistently

Results for the post-test environmental concepts questionnaires were better than the pre-test; children were able to save resources via practical actions, but unable to use recycled plastic bags. The number of children who brought cotton hankies increased from 1-2 persons to 7-8 persons-an obvious improvement-and children replaced tissue papers by cotton hankies for dry hands. Children knew not only the importance of having cotton hankies but also were willing to practice it. Children also reduced the use of water spontaneously when washing hands, without a teacher reminder. Moreover, children also washed hands rapidly and then immediately turned off the faucet; when seeing other children use too much water, the others would spontaneously remind them to reduce water waste. With regard to paper, children used both sides of drawing paper or used scrap paper to draw. The homeroom teacher did not see drawing papers with scribbles in the art center at the beginning of the fall semester. With regard to electricity, parents reported that children were more spontaneous about turning off the lights and television at home. Six parents stated that the time their children spent watching television decreased compared to the beginning of the semester. In the post-test questionnaire, most children said that they spontaneously turned off lights and the television at home, and did not keep opening the fridge door. Finally, with regard to plastic, while children already knew that shopping with shopping bags was more environmentally friendly, they did not practice the action.

\section{Recommendations}

The entire study mainly focused on investigating children's school performance. The researcher seldom interacted with parents, only implementing the pre-test and post-test questionnaires to them. Thus, the researcher was unable to observe children's real performance at home. In this study, children did not increase their re-use of plastic bags, which may have related to parents' degree of adaptability. The researcher suggests that educators contact parents in person or through teacher-parent communication logs. A part of parenting education could involve assisting parents in implementing children's environmental education at home. Furthermore, parents may help educators to cultivate children's environmental practices at home in this way.

\section{References}

Aguirre-Bielschowsky, I., Freeman, C., \& Vass, E. (2012). Influences on children's environmental cognition: A comparative analysis of New Zealand and Mexico. Environmental Education Research, 18(1), 91-115. http://dx.doi.org/10.1080/13504622.2011.582093

Ahlness, M. (1999). The earth groceries project. Science and Children, 36(7), 32-35.

Allman, S. A., Kopp, O. W., \& Zufelt, D. L. (1982). Environmental education: A promise for the future. Boston, Massachusetts: American Press.

Chang, Y. T. (2004). To evaluate the Energy Integrated Education Curriculum's experiments and to work on a probe into the influence about students saving energy's attitudes (Unpublished master's thesis). National Taichung University, Taichung.

Chawla, L. (1998). Significant life experiences revisited: A review of research on sources of environmental sensitivity. The Journal of Environmental Education, 29(3), 11-21. http://dx.doi.org/10.1080/1350462980040402

Chen, P. H. (2009). A study on applying picture books in environmental education for school children-an example of global warming (Unpublished master's thesis). National Chiayi University, Chiayi.

Chien, S. C. (2004). A Research of Environmental Issues Teaching through the Story Material - Focus on the Example of Conservation of Nature and Ecology (Unpublished master's thesis). National Taipei University of Education, Taipei.

Debby, M. Z. (2007). What can you learn from bombaloo? Using picture books to help young students with special needs regulate their emotions. Teaching Exceptional Children, 39(3), 32-39.

Environmental Education Act. (2011). Laws and regulations database of the republic of China. Retrieved May 25, 2014, from the http://www.youtube.com/watch?v=yheseSCAK6s\&feature=related

Fang, S. J. (2003). Fun teaching: Picture books and language teaching. Taipei: Psychological Publishing Co., Ltd. 
Hadzigeorgiou, Y., Prevezanou, B., Kabouropoulou, M., \& Konsolas, M. (2011). Teaching about the importance of trees: A study with young children. Environmental Education Research, 17(2), 519-536. http://dx.doi.org/10.1080/13504622.2010.549938

Hirsh-Pasek, K., \& Golinkoff, R. M. (2003). Einstein never used flash cards: How our children really learn and why they need to play more and memorize less. New York: Rodale.

Hsiao, C. Y. (2010). Enhancing Children's Artistic and Creative Thinking and Drawing Performance through Appreciating Picture Books Activities. The International Journal of Art \& Design Education, 29(2), 143-152. http://dx.doi.org/10.1111/j.1476-8070.2010.01642.x

Hsieh, F. H. (2012). A Case Study of the Community Resources Integrated into Theme Curriculum in Kindergarten (Unpublished doctoral dissertation). National Kaohsiung Normal University, Kaohsiung.

Hsiung, C. T. (1996). Scientific significance of fairy tales in science teaching. Compulsory Education, 36(3), 26-31.

Hsu, H. N. (2010). Kindergarteners' reading responses to environmental protection picture books (Unpublished master's thesis). National Chiayi University, Chiayi.

Huang, W. S. (2010). Major thinkers on early childhood education cite in picture books. In W. S. Huang (Ed.), The picture books teaching philosophy and practice in kindergarten (pp. 5-22). Taipei: Xiu-Wei.

Kao, H. H. (2011). An action research of instructing the concepts of saving energy to young children. In R. F. Chen (Ed.), Proceedings of the multiple aspects of children's learning (pp. 66-82). Taipei: Wu-Nan.

Kou, S. Y. (2008). Low Grade students Environmental Education through Story Teaching Focus on the Example of Animal Protection Picture Books (Unpublished master's thesis). National Taipei University, Taipei.

Li, S. H. (2007). The Action Research of Incorporating Picture Books into Environmental Education by Teachers of First and Second Grades (Unpublished master's thesis). National Dong Hwa University, Hualien.

Lin, F. A. (2008). A study of teaching ecological picture book creation at an elementary school-Taking schoolyard plants as an example (Unpublished master's thesis). National Dong Hwa University, Hualien.

Lin, M. C. (2008). A new method for children's reading. Taipei: Tien-Wei.

Lin, M. Y. (2008). Appreciation and application of picture books. Taipei: Psychological Publishing Co., Ltd.

Liu, M. L. (2002). A Research of Environmental Issue Teaching through the Media of Picture Books (Unpublished master's thesis). National Taipei University, Taipei.

Liu, M. L., \& Wang, P. L. (2003). A research on using picture books as the medium to teach environmental issues. Journal of Environmental Education Research, 2, 93-122.

Liu, S. T., Chen, C. C., Wu, L. C., \& Lin, S. H. (2010). The effectiveness of the Little Green Sprout Award Curriculum on elementary school students' daily environmental practices. Journal of Environmental Education Research, 2, 93-122.

Lu, X. (2005). Selected stories of Lu Xun. Beijing: Ren-Min-Wen-Xue.

Ministry of Education. (2003). The grade 1-9 curriculum guidelines. Taipei: Ministry of Education.

Monhardt, R., \& Monhardt, L. (2000). Children's literature and environment issue: Heart over mind. Reading Horizons, 40(3), 175-184.

Ning, F. T. (2004). Reading, pleasure reading: Set a bridge between teachers and students on sharing reading. Guo Jiao Shi Ji, 211, 65-72.

Ning, F. T. (2005). The study of the environmental concept of the 3rd year students under the teaching of picture books. Educational Journal of NHCUE, 10, 255-273.

Sun, A. J. (2011). An action research of implementation environmental research in kindergarten (Unpublished master's thesis). Fu Jen Catholic University, Taipei.

Tanner, T. (1980). Significant life experience: A new research area in environmental education. Journal of Environmental Education, 11(4), 20-24. http://dx.doi.org/10.1080/1350462980040402

Tien, Y. F., \& Wu, H. C. (2010). A study of environmental education content presented in high-quality picture books: Samples recommended by Taichung county early childhood teachers. Journal of Environmental Education Research, 8(1), 63-93. 
Walden, T. A., \& Baxter, A. (1989). The effect of context and age on social referencing. Child Development, 60, 1511-1518. http://dx.doi.org/10.2307/1130939

Wang, L. M. (2011). The effect of the teaching of picture books on junior elementary students' environmental awareness (Unpublished master's thesis). National Chiayi University, Chiayi.

Wang, S. H., \& Hu, B. L. (2002). The research of infusing the issues of global environmental pollution into AIT subject in elementary school. Chung Yuan Journal of Design, 4(1), 67-85.

Wells, R., \& Zeece, P. D. (2007). My place in my world: Literature for place-based environmental education. Early Childhood Education Journal, 35(3), 285-291. http://dx.doi.org/10.1007/s10643-007-0181-8

Witt, S. D., \& Kimple, K. P. (2008). 'How does your garden grow?' Teaching preschool children about the environment. Early Child Development and Care, 178(1), 41-48. http://dx.doi.org/10.1080/03004430600601156

\section{Copyrights}

Copyright for this article is retained by the author(s), with first publication rights granted to the journal.

This is an open-access article distributed under the terms and conditions of the Creative Commons Attribution license (http://creativecommons.org/licenses/by/3.0/). 